\title{
USING MULTILEVEL MODELING TECHNIQUES FOR SOCIAL AND ECONOMIC MONITORING
}

\author{
Stanislav Dubykivskyi ${ }^{1}$, Sergiy Holub ${ }^{2}$
}

\begin{abstract}
This paper studies the experience of applying the existing methods of modeling in the field of economic monitoring. The method of Group Method of Data Handling (GMDH) is suggested as an alternative for economic modeling. The research calculates and builds inductive models describing gross domestic productivity (GDP) using economic indices that are characteristic of the countries with developed information economies. The resulting models are then clustered by similar features. The obtained results are briefly analyzed.
\end{abstract}

JEL Classification Numbers: C00, O1, F5, DOI: http://dx.doi.org/10.12955/cbup.v4.750

Keywords: multilevel modeling, information economy, GMDH, economic monitoring, model of development.

\section{Introduction}

Today, much attention is drawn to various methods of studying the economy. The dynamic development of the modern society over the past decades has assisted in transitioning from an industrial society to an information society. As a result, a new type of economy is being formed, an information economy, which is driven and powered by information, knowledge, information and communication technology (ICT), and specialized infrastructure. The information economy is essentially open. The degree of this economy's openness indicates the level of its reliance on the global market and is a main criterion of economic growth and security (Dubykivskyi, 2014). Growing openness of national economies has been brought about by countries' gradually integrating into the multidimensional system of a global economic era in a developing information society. Calls abound for appropriate assessments of the integration, and increased professional attention to the issue of correlating personal, social, and state interests. As the information economy is characterized by high dynamics that is essentially different from the industrial economy, the issue of using new approaches emerge including economic and mathematical methods of monitoring the trends. The countries with a developed information economy are the world's leaders in many respects. Therefore, studying their specific features makes it possible to see both positive and negative trends, which, in turn, creates opportunities for adequate and prompt adjusting of a state's economic thrust.

\section{Materials and Methods}

The issues of specific information economy country models have received enormous attention. It is worth noting the research of Schumpeter (2007), Castells and Himanen (2002), Averkin (1986), Ayvazian (1974), Heyets, Kyzym, Klebanova and Chernyak (2006), Suhorukov (2013), and Ivahnenko and Yurachkovsky (1987). Overall, many involve the theoretical basis for studying the information economy country models, and others study the conceptual issues of countries' development and security in the information society.

Economic monitoring is important for observing economic processes and phenomena and is a tool for identifying trends and making forecasts. The aforementioned works examined the concepts and models of social and economic development, which are described by a system of important indicators. Index values are compared with recorded values. After the comparison, results are analyzed, weaknesses are identified, and ways to decrease negative effects on a national economy recommended. Such an analysis can describe the social and economic state of a country over a particular time period.

One of the main flaws of this approach is that common statistical modeling methods require the variables in the data array to fit Gauss' normal distribution law. Also, models need to take into account the deep internal links between the elements. Another drawback is that the process is essentially a 'reactive and catching up' model of economic defense. The 'reacting' mechanism only triggers a corresponding response when there is a negative effect, in contrast to the 'proactive' model, which

\footnotetext{
${ }^{1}$ Stanislav Dubykivskyi, Institute of Social and Economic Development, Kyiv, Ukraine, info@ isedworld.org

${ }^{2}$ Sergiy Holub, Institute of Social and Economic Development, Kyiv, Ukraine
} 
involves a backup resource and uses anticipatory steps. The proactive model is factor-driven and target-oriented, and targets potential inner sources of negative phenomena rather than outer dangers.

To remove the abovementioned flaws, an alternative approach has been suggested. This is the method of multilevel information transformation to identify the quantitative indices of a country's economic state. It is based on the Gross Domestic Productivity (GDP) calculation as a target function that indicates secure economic development.

To solve this task, this study examines countries with developed information economies, China, which has an economy that is rapidly developing at present, and Ukraine (Table 1). The choice of countries was based on 'The world IT industry ranking' (Table 1), which uses data of the World Economic Forum (The Global Information Technology Report, 2013).

The country's GDP is a quantitative index of social and economic development and economic security for the countries with a developed information economy. Therefore, it is important to find the level at which the relevant components, typical for the information economy, influence the formation and value of the GDP. A data array of indices, typical of the information economy and which describe its state, for these countries for the period between 2000 and 2013 was created. The input to the data array (IDA) included the absolute values of the following indices: GDP, GDP per capita, foreign trade turnover per capita, state debt, foreign debt, high tech commodity export, information and communication technology (ICT) commodity export, ICT commodity import, gross domestic expenditure on research and development (R\&D), ICT service export, and ICT service import. The data were collected and calculated from universally accepted statistical resources (Unctad and Worldbank).

Table 1: The world information and technology industry ranking

\begin{tabular}{|l|r|r|}
\hline \multicolumn{1}{|c|}{ Country } & \multicolumn{1}{c|}{$\begin{array}{c}2014 \\
\text { ranking }\end{array}$} & $\begin{array}{c}\text { 2013 } \\
\text { ranking }\end{array}$ \\
\hline Finland & 1 & 1 \\
\hline Singapore & 2 & 2 \\
\hline Sweden & 3 & 3 \\
\hline Netherlands & 4 & 4 \\
\hline Norway & 5 & 5 \\
\hline USA & 7 & 9 \\
\hline Japan & 16 & 21 \\
\hline Canada & 17 & 20 \\
\hline New Zealand & 20 & 58 \\
\hline China & 62 & 73 \\
\hline Ukraine & 81 & 2 \\
\hline
\end{tabular}

Source: The Global Information Technology Report (2013)

Using common statistical modeling methods essentially means bringing the variables in the data array in accordance with Gauss' normal distribution law. The task involved identifying the functional relationship,

$$
\mathrm{Y}=\mathrm{f}(\mathrm{X})
$$

where $Y=\left\{y_{1}, y_{2}, \ldots, y_{m}\right\}$, the set of information economy's features (GDP); and

$\mathrm{X}=\left\{\mathrm{x}_{1}, \mathrm{X}_{2}, \ldots, \mathrm{X}_{\mathrm{n}}\right\}$, the features of the conditions forming it.

To solve this task, the inductive Group Method of Data Handling (GMDH; Ivahnenko \& Yurachkovsky, 1987) was used in the form of an automated data multilevel transformation system.

It is notable that Group Method of Data Handling (GMDH) is universally accepted and has a wide range of applications (Holub, 2007). This method is used when there is a lack of information and in this case the hidden deep correlations and influencing factors between the elements of dynamic systems were unknown. 


\section{Results}

The modeling obtained and tested inductive models that described the formation of countries' GDPs by the features of 'array X', with the models built on one sequence and tested with another. In this case, a model was built on sequences from the 2000 to 2010 period and tested at observation points in multidimensional space of array X features over the period 2011 to 2013. As a result, the models were synthesized and grouped by features into seven clusters (Table 2). The coefficients for the model variables with the highest indices showed the greatest influence among these indices on a country's GDP growth (Table 2).

Table 2: Clustering the synthesized models by coefficients of model variables

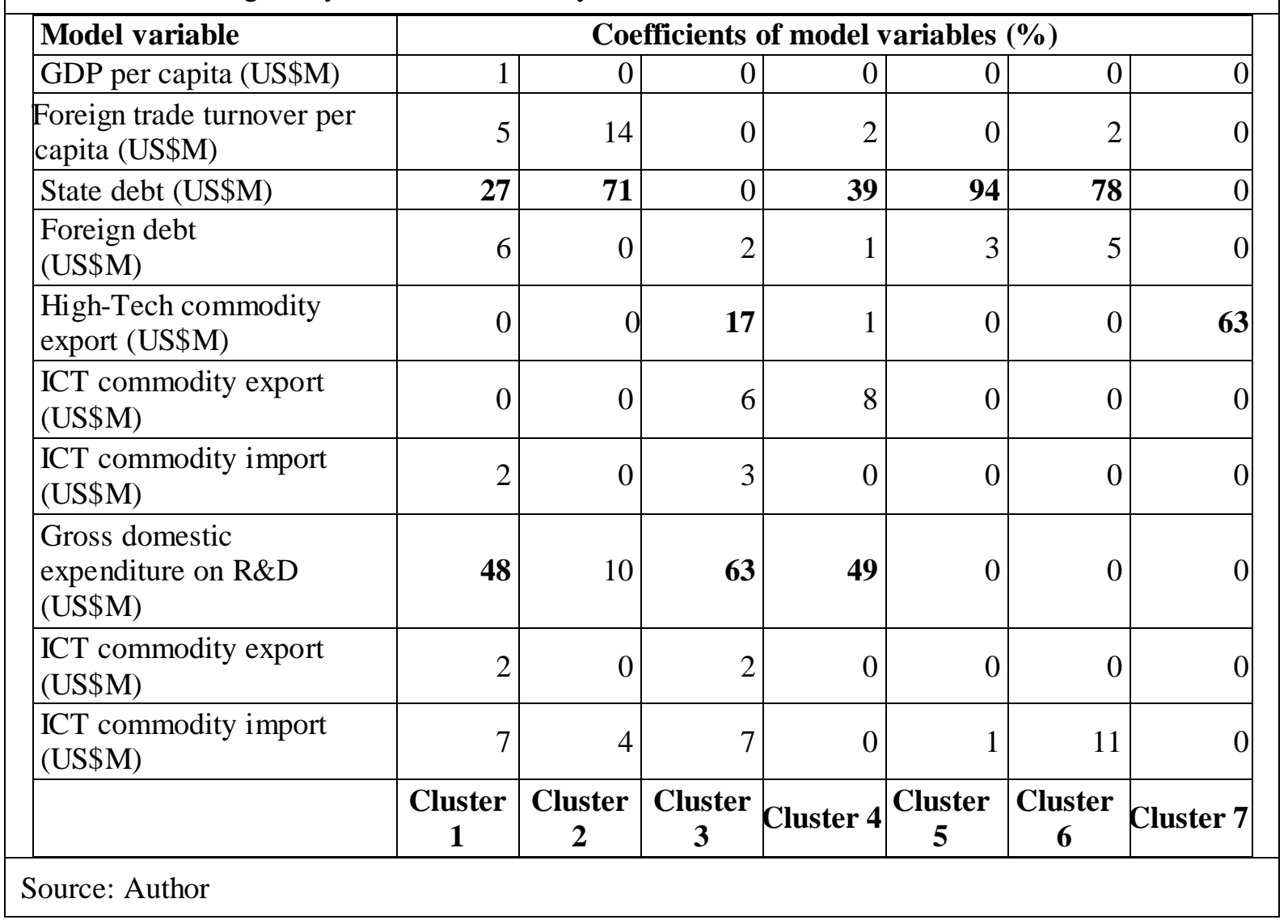

Cluster 5 embraced such national economies as Netherlands in 2000, Finland and Sweden in 2005, Norway and Japan in 2008, Sweden in 2009, and New Zealand in 2010. Ukraine's economy in 2009 and 2010 did not quite reach the status of Cluster 5 for the state's debt influence on the GDP. This was because, at that time, Ukraine's state debt did not reach beyond the critical values and, therefore, did not affect the GDP. Due to the value of hi-tech commodity exports, especially the airspace industry, Ukraine's economy was a part of Cluster 7 in 2005 and 2008, along with Finland in 2000 and 2010, and Norway in 2009. This was due to Ukraine signing contracts for the export of domestic airspace commodities. Overall, clustering the synthesized models by coefficients of model variables explained how some countries in a particular period shared features which influenced the GDP.

\section{Discussion}

To study the features of the economic growth of countries with an information economy, a Group Method of Data Handling (GMDH) for inductive models was used to describe the GDPs by features of indices that were typical for the countries with developed information economies. The program produced adequate models that tested, checked, and grouped seven clusters by similar features. The models involved a huge polynomial that lacked useful information. The most important influence were the coefficients of model variables, with several indicated as having the greatest effect on the GDP value and the state of a country's economic security. Thus, according to calculations, the main features for GDP conditions are gross domestic expenditure on R\&D (Clusters 1,3, and 4), state debt (Clusters 1, 2, 4, 5, and 6), and hi-tech commodity export (Clusters 3 and 7). 
The obtained results fully described the real state of countries' information economy and were relevant for the current processes. The weakness of a state's economy is its unprotected social and economic areas, which introduces non-reversible technology, dragging behind the global economic development, probable social regress, and social disintegration.

\section{Conclusion}

As the countries with information economy are the leading countries in terms of social and economic development, their development models may be considered to be the best (proactive) models of economic security. The model of proactive development involves backup resources and uses proactive steps. This model's work can be compared with the electronic access code or password. While the code is being searched and deciphered, the system that does not stop developing and improving will find increasingly complicated and advanced security methods.

In future, the study of the features relating to countries with information economies will make it possible to grasp the global trends and adjust the development thrust of a national economy with the aim of avoiding negative effects in the information society era.

\section{References}

Averkin, A. (1986). Nechetkiye mnozhestva v modelyakh upravleniya i isskustvennogo intellekta [Vague Multitudes in Management and Artificial Intelligence Models], Nauka.

Ayvazian, S. (1974). Ob opyte primeneniya ekspertno-statisticheskogo metoda postroyeniya neizvestnoy tselevoy funktsii. V kn.: Mnogomernyy statisticheskiy analiz v sotsial'no-ekonomicheskikh issledovaniyakh [On the Experience of Applying the Expert and Statistical Method for Building an Unknown Target Function], Nauka.

Castells, M. \& Himanen, P. (2002). Informatsionnoye obshchestvo i gosudarstvo blagosostoyaniya: Finskaya model' [Information Society and the State of Well-being. The Finnish Model], Logos.

Dubykivskyi, S. (2014). General description of the state of economic security of countries under the conditions of the open economy. Journal L'association 1901 "SEPIKE"/ Poitiers France, Osthofen Deutschland, Los Angeles USA. 05, 116-121.

Heyets, V., Kyzym, M., Klebanova, M. \& Cherniak, T. (2006). Modelyuvannya yekonomíchnoï bezpeki: derzhava, regíon, pídpriêmstvo: monografiya [Modelling Economic Security: State, Region, Enterprise], Kharkiv National Economic University.

Holub., S. (2007). Bagatorívneve modelyuvannya v tekhnologíyakh monítoringu otochuyuchogo seredovishcha [Multilevel Modelling in the Technologies of Monitoring the Environment], Cherkasy National Bohdan Hmelnytsky University.

Ivahnenko, A. \& Yurachkovsky, Yu (1987). Modelirovaniye slozhnykh sistem po eksperimental'nym dannym [Modeling Complex Systems on Experimental Data], 'Radio I Sviaz'.

Schumpeter, V. (2007). Teoriya ekonomicheskogo razvitiya. Kapitalizm, sotsializm i demokratiya [The Theory of Economic Development], EKSMO.

Suhorukov, A. (2013). Shchodo metodologií kompleksnogo otsínyuvannya skladnikív yekonomíchnoï bezpeki derzhavi [On the Methods of Complex Assessment of a State's Economic Security], Strategic Priorities, 3(28), 5-8.

The Global Information Technology Report (2013). Growth and Jobs in a Hyperconnected World / Beñat Bilbao-Osorio, Soumitra Dutta, and Bruno Lanvin, Editors - r. 409. 